\title{
Corporate Social Responsibility on Shareholder Value with Leverage as Moderating Variable
}

\author{
Asim Ali Chaudhry, Suresh A/L Ramakrishnan, Ayesha Sharif
}

\begin{abstract}
From the last many years' educators, administrators and, researchers persistently devoting attention to corporate social responsibility. However, no study analyses the relationship between corporate social responsibility and shareholder value by using leverage as a moderator. The aim of this research is to produce a review to examine the effect of corporate social responsibility on shareholder value with leverage as a moderating variable. The stakeholder theory and agency theory are employed as underpinning theories. Little attention has been given in this area of study in the developing, emerging and developed economies particularly with leverage and shareholder value. Therefore, scholars and practitioners are motivated to advance the body of knowledge in this research field for the universal enrichment of output. As the review forms a concept of corporate social responsibility and shareholder value by using leverage as a moderator.
\end{abstract}

Index Terms: Corporate Social Responsibility; Leverage; Shareholder Value

\section{INTRODUCTION}

Corporate social responsibility (CSR) is an obligation of the firm to act in a rational way. It assumes donating a part of the earnings of the company for the improvement of society. Another way of defining CSR is by earning benefits by fulfilling legal obligations and offering respect to employees of the firm. In this way, CSR can be defined as the approach of getting economic success by promoting ethical values, caring and respecting the people at work, in the societies and the encircling environment. Commonly, it is considered that a company will be liable for all the conduct they do ethically and socially [1]. Firms that keep an eye on the interests of the needy peoples in society, gain' good reputation in society and that reputation is sold in the market. Such firms draw the attention of investors and thus easily get funds as compared to other firms [2].

A shareholder is a person with the ownership rights of a firm, where the rights are typically reflected in a firm's share of common stock [3]. Furthermore, shareholder's value can be produced, when the revenues generated from invested capital surpass the required rate of return on equity [4]. Moreover, in this competing world sustaining a durable relationship with the shareholders is important and it could happen only when the firm delivered better profits or value to the shareholders [4]. Many firms acknowledged the significance of shareholder value and started to implement initiatives for enhancing shareholder's wealth.

Revised Manuscript Received on November 15, 2019.

Asim Ali Chaudhry, Faculty of Azman Hashim International Business School (AHIBS), Universiti Teknologi Malaysia (UTM), 81310 Johor Bahru, Johor, Malaysia, Suresh A/L Ramakrishnan, Faculty of Azman Hashim International Business School (AHIBS), Universiti Teknologi Malaysia (UTM), 81310 Johor Bahru, Johor, Malaysia.

Ayesha Sharif, Faculty of Azman Hashim International Business School (AHIBS), Universiti Teknologi Malaysia (UTM), 81310 Johor Bahru, Johor, Malaysia.
Moreover, according to [5] that corporate social responsibility is beneficial for the firm. Furthermore,[6] defines CSR as those activities performed by the organization to improve some of the social aims beyond the interest of the company and the one which is required by law. As indicated by [7], the approach of CSR is the process that produces the harmony between the stakeholders and shareholders. The term CSR has not the same meaning for all stakeholders [8]. Moreover, according to [9], from the past few years in academic studies, the concept of CSR has realized the importance of evaluating its effect on the shareholders' value. Shareholder's first goal is the security of capital invested and the second is demands for significant returns on invested capital. Therefore, firms are devoting their first preference to the importance of shareholder's wealth, to gain long-run investments from shareholders by maintaining a trust relationship with them [10]. Moreover, the principle of shareholder wealth maximization mentions that the prompt operating objective and the ultimate aim of a corporation is and must be to enhance return on equity capital. The shareholder wealth maximization specification of what is frequently termed as a corporate goal makes operating objective and ultimate aim the same: investors and managers should concentrate closely on shareholder wealth maximization [11]. Moreover, [12] quoted, Friedman, that there is one responsibility of the management, to maximize the wealth of its owners or shareholders. The theory postulates that the financial objective of every organization or firm is the "maximization of shareholders wealth" as indicated in the company's market value of shares [13].

The concept of Corporate Social Responsibility has attained more spotlight as the world moves towards advanced globalization. According to [14] the approach of Corporate Social Responsibility has been strengthened with the establishment of globalization and liberalization. Moreover, in firms' operations enforcing Corporate Social Responsibility is a substitute to add sustainability.

Companies are trying to install sustainability into the body of their businesses. Furthermore, as stated by [15] that CSR has been increasingly highlighted as businesses explore to share their values with society. CSR is the volunteer practice of the company for the stakeholder's wellbeing and particularly the community [16]. In addition, shareholders judge the CSR engagements as a silent signal for their distinctness with the company [17]. According to [18] CSR can be defined as a process of the firms to make profits and they should do it according to the conduct of the responsibility towards society. 


\section{Corporate Social Responsibility on Shareholder Value with Leverage as Moderating Variable}

The objective of Hopkins is to implement CSR in the form of living standards that will upgrade when the profits of the organization's increases and in result living standards should sustain for both the peoples that live inside and outside the boundaries of the organization. Furthermore,[19] had mentioned that in the last 45 years CSR prevails in the management and academic literature. In recent years, companies and societies have mutually increased their focus on corporate social responsibility [20-22]. Generally, companies focus on the profits and business operations, but in recent years improvements in the CSR activities made by the companies in their businesses that serve the society as well. Researchers have named these activities as CSR [23, 24]. For the company, there are many reasons to implement corporate social responsibility practices, but its popularity can be the main feature to implement corporate social responsibility engagements [25]. In these days firms are also focusing on CSR related to environment [26]. Furthermore, according to [27] if the firms work in the interest of stakeholders it ultimately influences the wealth of shareholders in a positive way as well as maximizes the returns of shareholders.Moreover, Corporate social responsibility affects positively organizations interactions with competitors and customers and decreases the cost of high leverage. CSR minimizes the failures in the market share even company are highly leveraged. Minimizing the unfavorable conduct by competitors and customers, CSR provides help to highly leveraged companies to intact with customers and protect against competitor's predation [28]. In addition, customers that are socially responsible, when compare with CSR company's, found faithful, strong to deny negative information to these companies, and are agreeing to pay a greater price [29]. As [30] establish a theory that companies that are doing CSR activities can charge greater prices and they face less price elastic demand. So, these companies' cash flows turn into less unstable across the business cycle, this permits them to obtain optimal leverage. CSR companies can best sustain against unfavorable results of high leverage because they face minimum negative reactions from stakeholders in response to high leverage. In addition, CSR firms face the low cost of high leverage. Particularly, there exist two possibilities to anticipate low costs of high leverage in CSR companies. First, CSR is linked with a halo effect that enhances trust among company and stakeholder groups, which will pay off in stiff times [31, 32]. The halo effect of CSR contributes to protection like insurance in highly leveraged companies and minimizes chances for competitors to take advantage of the weak financial position of highly leveraged companies. For example, customers have an expectation that CSR company will not break implicit contracts (e.g., promises of job security to employees and continued service to customers) even in the worst financial conditions, customers are very certain in this matter. Second, it is perceived that companies engage in CSR activities face a minimum level of risk that is (lower litigation risk) and have strong investor support [33-35]. So, companies that are engaged in CSR practices have the best accessibility to financing and have less capital cost [36-38], which reduces the cost imposed on the company by rapacious attacks from competitors.According to [39, 40], debt is an imminent option at country and firm levels, especially in developing economies. Moreover, it is an advantage for a firm to mix its borrowed capital with the owner's capital as such a capital enhances shareholder value [41]. Furthermore, the main goal of financial managers in today's world of competitiveness is to create shareholder value. The wealth formed by the firm for its shareholders is called shareholder value [10]. Leverage is defined as the competency of the organization in the financing, by utilizing the mixture of debt and equity to enhance the value of the firm. It has been complicated for the managers to select a suitable mixture of debt and equity to appeal to the creditors and shareholders. A suitable debt-equity mix can minimize the cost of capital that is matched with the company objective to reduce the cost of capital to increase shareholder value [42]. Cost of capital is a single influential factor for investors in making an investment or project financing and in establishing the value of shareholders [43]. Selecting the suitable debt-equity mix will result in the minimal average cost of capital which leads to an increase in the per-share market value [44]. With the lower capital cost, higher returns can be achieved by maximizing the wealth for shareholders [45]. In an organization among all other decisions made by managers, financing decision is one of the most complicated in nature which has an impact on firm performance [46].

\section{CONCEPTUAL FRAMEWORK BASED ON THEORETICAL FOUNDATION}

The stakeholder approach holds the opposite view to the shareholder approach that the eventual responsibility of the organization is not only to enhance shareholders value but to work for all stakeholders that belong to the community in which organization functions [47], without prioritizing one stakeholder on another in promising trade-offs [48]. As stated by [49] that the eventual goal of corporate managers should be to enhance the wealth of all stakeholders, because, in this way, the value of shareholders can be maximized. Moreover, according to this argument, it realizes that the two approaches do not conflict with each other rather they are compatible [48]. Furthermore, according to [50] mentioned that initially, stakeholder theory gives priority to shareholder's interests, and they built a case for the theory's normative base, where legal, ethical and moral claims were advocated concerning all stakeholders. The CSR and shareholder maximization approach is in line with stakeholder theory [51, 52]. In addition, according to [53], market-based measures shows the notion that shareholders are the most valuable group of stakeholder, whose satisfaction decide the companies fate. Furthermore, product-related, workforce, community and environment are also considered stakeholders of the organization [54, 55] Moreover, the stakeholder's theory's objective is to merge social responsibility into business organizations without compromising the interest of the shareholders nor the basis of the capitalistic market financial system [47].

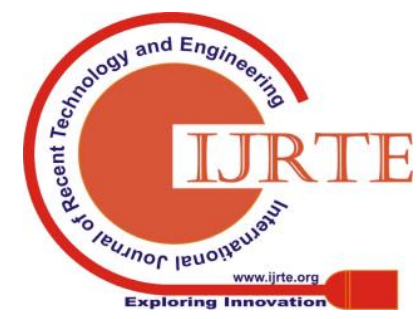


In addition, [56] view the stakeholder approach as a good management idea, and firms that are efficiently managed in his view will produce maximum profits. Furthermore, [57] defines firm stakeholder "any group or individual who can affect or affected by the achievement of an organization's purpose". Agency theory is about conflict of interest that may arise between the agent (Management) and the principal (shareholder). The theory of the firm was proposed by [58], which is based upon two key concepts one is asymmetric information and the second is the creation of incentives. This theory argues that agency problem is raised under the condition of asymmetric information because the manager is well informed about the company's growth and other financial indicators so they can increase debt in the capital structure [59]. Furthermore, managers are more experts then shareholders (Principal) therefore; sometimes managers make a decision for the betterment of the company on the cost of shareholders. If both parties have the same goal for maximizing the value of the company, it is believed that the agent will act in a manner that is in accordance with the principal's interests [58]. According to the theory of the experts put forward by [58] indicates that according to agency theory a firm having high leverage would have a high agency cost. To accentuate profit and to cover the bad signal, a firm will decrease social costs such as CSR activities cost, for the purpose to show their profits [60]. Agency theory recommends that agency costs should be minimum and by having efficient deals between investors and management they should maximize shareholders' wealth [61]. Agency theory [58] suggests that the selection of capital structure can help to reduce agency costs. Under the hypothesis of agency cost, low equity/asset ratio or high leverage minimize the agency costs of outside equity and boosts company value by encouraging or constraining managers to work more in the shareholders' interests. Higher financial leverage may influence managers and minimize agency costs through the danger of liquidation, which affects managers' reputation, perquisites and personal losses of salaries [46]. Greater leverage can minimize clashes among managers and shareholders regarding the decision of investment [62], the proportion of risk to engage in [63], the circumstances in which the organization faces liquidation [64], and policy of the dividend [65].

\section{A. Corporate Social Responsibility}

According to [66] the independent variable is a variable (criterion) that assumed to have an impact on the dependent variable. World Business Council for Sustainable Development defines CSR as: "the continuing commitment by business to behave ethically and contribute to economic development while improving the quality of life of the workforce and their families as well as of the local community and society at large" [67]. The European Commission defines CSR as: "Being socially responsible means not fulfilling legal expectations, but also going beyond compliance and investing more into human capital, the environment and relations with stakeholders" [68].

Corporate social responsibility is a general idea that encourages different types of activities or social liabilities on a voluntary basis. Activities which is called social directly linked with businesses, if the business engages them, they have a direct positive effect on the business [6971]. For instance, the positive image of the company transferred in the society and the morale of the employees also increases, which in result increases the productivity of the company [69]. Furthermore, scholars and researchers consider that corporate social relationship between firms and the community needs to be enhanced otherwise it may have serious effects as it can destroy or create shareholders' value and may also hamper their performance. CSR practices help the firms to hold a strong position [24, 72].

\section{B. Shareholder Value}

A dependent variable is also called the response variable, which is being statistically analyzed. Value theory indicates that the main objective of the company is profit-maximizing and mainly the present value of the company. From a view of classical theory, those companies which are not capable to maximize profits are replaced by others or disappears and companies survive only which can maximize profits [73]. Moreover, [74] mentioned that the primary obligation of any organization is to maximize the wealth to its shareholders. The financial professionals of the present-day have underlined the concept of wealth maximization of the owner or principal of the firms i.e. shareholders [13].

\section{Leverage}

Moderator is a variable that affects the direction and strength of the relationship between an independent or predictor variable and dependent or criterion variable [75]. The moderator effect of variable occurs when a third variable changes the effect of the association between the determinant and outcome construct by either reserve the direction or decrease the magnitude of the association [76]. Base on empirical evidence, leverage is usually proposed as the predictor variable in various studies [41, 77-79]. However, in this current research, leverage is postulated to play a moderator role in the relationship between CSR and shareholder value.To increase the potential returns on investments by using debt is called leverage in finance [80]. For instance, the degree that a firm borrows money to finance investments is the definition of leverage, by applying this definition $[80,81]$ finds in their examination that firms may lead to bankruptcy when they are excessive in leverage, the probability will be higher if the market downturns. The company may face difficulties in financing their operations in the future and may frequently fail to pay to their creditors when they fall in highly leveraged firms. Strategies of financial leverage are benefited if they are executed with diligence otherwise these strategies are complex and highly risky [80].

In improving the company's wealth, the use of debt is called financial leverage [82]. The leverage ratio is the most widely used measure of leverage indicated by total debt to total equity ratio [83]. For decision making and investment purposes, a high leverage ratio may adverse for firms as compared to low leverage ratios [80]. 
According to [84] revealed that leverage is a part of the company's fundamental financial performance, leverage shows the company's ability to manage the funds' sources both from debt or from assets owned by the company. The increase in leverage ratio shows the high need of the company for fresh funds, besides the high value of leverage also reveals the dependency of companies on debt that can create risks for survival of the company. Leverage is an efficiency indicator of the company's business activities and risk-sharing business between the owner of the company and the loan givers or creditors. For example; interest expense on debt is credit from banks and other financial institutions. The smaller the number of loans, the interest credit burden is also small on the company. Thus, in terms of interest expense, the company is more efficient in business operations. If the other operational costs are reasonable, with small loan interest charges expected the profitability of the company increased [85]. The leverage ratio is used to give a description of the capital structure of the company, so it can be viewed through the uncollectible risk of debt [86]. Financial leverage is the use of debt in increasing corporate profits [82]. Furthermore, [87] stated that the use of funding through debt will have three important implications, namely:

1. Obtaining funds through debt will make shareholders control the company with a limited amount of equity investment.

2. Creditors see the capital provided by shareholders as a safety limit so that if the higher the proportion of capital that is given by shareholders, the smaller the risk faced by creditors.

3. If the results obtained from the company's assets are higher than the interest paid, then the use of debt will increase returns on equity.

Companies that have a greater proportion of debt in the capital structure will have more agency costs [88]. According to [89], leverage is a ratio that measures how much the company is financed with debt. Leverage is a ratio that describes the relationship between company debt to capital, this ratio can see how far the company is financed by debt or outsiders with illustrated company capabilities by capital. In this case, the leverage is represented by debt to equity ratio, which according to [90], the comparison of debt and equity in the financial structure of a company is called capital structure. To determine the optimal capital structure, Debt to Equity Ratio (DER) proxy is used because it reflects the proportion between total debt and total equity. Total debt is total liabilities (both short- and long-term debt), while total equity is the difference between total assets and total liabilities. Debt to Equity Ratio is closely related to the creation of a capital structure that can influence an appropriate corporate funding policy to maximize the value of the company, the higher the DER ratio value, illustrates the less favorable symptoms of the company because higher the financial risk. Increased debt will turn to affect the size of net profit available to shareholders' including dividends received due to the obligation to pay more debt. Investors prefer low DER levels because the level of security of the funds will be better so that the expected returns of the company will also be high.

\section{DEVELOPMENT OF HYPOTHESIS IN RELATION TO THE CONCEPTUAL FRAMEWORK.}

\section{A. Corporate Social Responsibility \& Shareholder Value}

CSR has a positive impact on shareholder's value. According to [91] that from the perspective of stakeholders' CSR has a positive impact on corporate financial performance. Because the company has in relationship with different stakeholders such as consumers, government, environmental advocates and competitors, enhancing in social contribution could promote stakeholder relationships, which results in decrease firms' social cost and boosts market opportunities, directing to maximum financial performance. Furthermore, [92] show that companies with a higher CSR rating normally produce maximum returns as compared to low CSR ratings. In addition, [93] show that investing in corporate citizens generates exclusive market performance. Moreover, [94] mentioned that managers use CSR commitments to solve conflicts between stakeholders and that increases shareholders' value. Similarly, [95] find that CSR activities positively impact on firm's financial performance because CSR engagements can solve issues between stakeholders and managers. As $[96,97]$ mentioned that when a firm is involved in CSR practices, it increases shareholders' confidence. According to [98], CSR as a company motive not only to generate traditional profit but also donate to the community for long-run survival. Thus, CSR is related to the real value that a company generates for its investors: customers, communities, creditors, and society [99]. Furthermore, [100] found that companies can gain a competitive advantage over their competitors by spending on societal engagements. In a research conducted on twenty firms in Pakistan, it is established that CSR has a positive relationship with financial performance and shareholders' wealth. This study which was conducted by [101] aimed to investigate the concept of CSR on the firm's financial performance and on shareholders' wealth. It was making a comparison of ten CSR firms and ten non-CSR firms by using a mixed methodology. It was used ROA, ROE, and Profitability Ratios as financial performance measures and EPS for shareholder wealth. It was observed that CSR firms have a high ratio of ROA and ROE as compared to non-CSR firms. Similar is the case with EPS that has high in CSR firms while as low in non-CSR firms. It was found that CSR activities are vital for organizations to achieve shareholders' wealth and financial performance. Firms that are involved in CSR practices accordingly CSR paybacks to those firms in a positive way as compared to non-CSR firms. Studies that have been conducted on the relationship between CSR and shareholder's value mostly confirmed the positive effect of CSR on shareholders' value. In the Korean context, a study conducted by [102] examines the relationship between CSR, product market competition (PMC) and shareholder wealth. It was used data from 2006-2012 and Fama Macbeth's crosssectional regression for analysis.

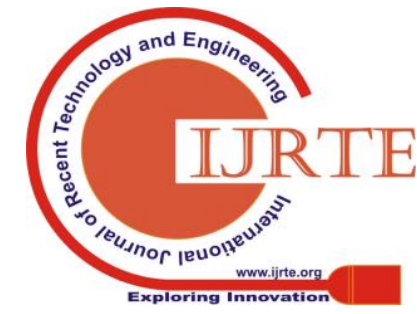


Results show that PMC plays a significant role in CSR activity and stock returns when PMC is low. The results show that when the competition is low, the impact of CSR on shareholder's wealth is consistent. In another study in a Chinese context, a study based on 3462 observations from 2006-2014 conducted by [103]. The purpose of this study to find the relationship between CSRD and firm performance and ownership structure role in state and nonstate-owned firms in china. It was used performance measures such as ROA, Tobin's Q and EPS. By applying regression analysis, it was found that CSRD has a positively associated with Tobin's Q and ROA. The results also revealed that CSRD has a significant relationship with ownership structure but adversely associated. It was also found that nonstate-owned firms disclose more information as compared to state-owned firms and the effect of CSRD on performance varies accordingly. The authors suggest that the government needs to consider private-public sector partnerships to enhance the quality of CSRD and firm performance. Based on above the hypothesis is,

H1: CSR has a positive relationship with the shareholder value of companies.

\section{B. Moderating Effect of Leverage between Corporate Social Responsibility \& Shareholder Value}

This current research also aims to study the moderating effect of leverage on CSR and shareholder value. Leverage indicates a company's capital structure and is a vital index for a company's financial distress. Leverage may enhance interest burdens and business operating risk [104]. Leverage is measured by the ratio of long-term debt to total assets [105]. Similarly [106] indicates, the extent to which a company employs financial leverage or debt funding has implications for the company. Shareholders are able to maintain control by lifting funds through debt without increasing the investment. Moreover, if a company acquires more on the investment financed with debt than on debt interest is due, than shareholders' value is leveraged. Furthermore, [107] mentioned that capital structure is the relative amount of debt and equity a company employs to finance its operational activities. The greater the debt-equity ratio, the greater the amount of debts utilize to produce profits [108]. Moreover, according to [109] who revealed that debt is an important instrument that can increase the company value if funds are managed appropriately. Furthermore, [84] indicates that increasing the value of debt will increase the flow of funds that goes into the company's cash that can be used to increase the achievement of financial performance or increase the portion of the success of the activity outside operations such as CSR. According to $[110,111]$ firms that have high leverage will reduce CSR disclosure because they don't want to be in the spotlight of debtholders. In addition, [112] explains that leverage and profitability have no significant effect on CSR disclosure. Through the study of [113], the same outcome obtained that leverage and profitability has no impact on CSR disclosure. These findings suggest that firms are focusing only on profit and no attention is paying to CSR activities and community. When firms implement CSR as a result cost increases of firms. This cost will ultimately evolve into a burden that lessens revenue and make a reduction in firm profit.
Therefore, by implementing CSR, it is assumed that the profitability of a firm also inclines [114]. In contrast, [101] indicates that when the firm work for their stakeholders that assist in accomplishing long-run success and maximizing profits, it also influences the wealth of shareholders in a positive way as they are anxious with the firm profitability from which they can attain maximum returns.Moreover, [115-118] mentions that high leverage companies for reducing agency costs tend to disclose more sustainability information. These authors find a positive relationship between CSR disclosure and financial leverage. Furthermore, a study conducted by [119] examined the impact of capital structure and cost of capital on shareholders' wealth maximization. The results showed that a linear relationship between shareholders' wealth maximization and cost of capital exists while there is no relationship between capital structure and shareholder wealth maximization. Similarly, a study conducted by [41] examines the effect of financial leverage on shareholder return on pharmaceutical firms in the National Stock Exchange (India). The findings show that financial leverage is significantly related to shareholder return. Likewise, in the same vein, a study conducted by [4] examined the relationship between capital structure and shareholders' value. By applying the regression model on the panel data, it was found that a positive correlation exists between CSV and debt-equity ratio, short-term debt ratio and long-term debt ratio. It was mentioned that the DE mix used by the company will influence the shareholders' wealth. Lastly, the researchers highlighted the importance of leverage as a moderator in the relationship between CSR and Financial performance [120]. Similarly, in another study [121] investigated the role of leverage as a moderator between CSR and firm value. In the same vein, another study conducted by [60] viewed the role of leverage as a moderator between Good Corporate Governance and CSR. However, a review of the comprehensive literature indicates that the moderating impact of leverage in the relationship between CSR and shareholder value is yet to be explored. Therefore, this research investigates the moderating impact of leverage in the relationship between CSR and shareholder value. Based on aforementioned the hypothesis is,

$\mathrm{H} 2$ : Leverage may moderate the relationship between CSR and shareholder's value of companies.

\section{CONCLUSION AND RECOMMENDATIONS FOR FUTURE RESEARCH}

Corporate social responsibility has attracted worldwide attention since the 1990s. The moderating effects of leverage on CSR and shareholder value have not been explored yet. This study aims to determine whether corporate social responsibility (CSR) affects the value of the shareholder value and leverage as a moderating variable. For future research, this model can be applied to other developing, emerging and developed economies of the world and can be made a comparison of cross-culture countries. 


\section{Corporate Social Responsibility on Shareholder Value with Leverage as Moderating Variable}

\section{REFERENCES}

1. 1.Chaudhry, A.A. and S.A.L. Ramakrishnan, Corporate social responsibility, brand equity, and shareholder value: Theoretical and conceptual perspectives. International Journal of Recent Technology and Engineering, 2019. 8(2 Special Issue 9): p. 22-31.

2. Qazi, S., et al., Company's financial performance and CSR: Pakistan context. Global Advanced Research Journal of Management and Business Studies, 2015. 4(5): p. 196-202.

3. Brealey, R.A., et al., Principles of corporate finance. 2012: Tata McGraw-Hill Education.

4. Venugopal, M., B.P.S. G., and R. Reddy, Impact of Capital Structure on Shareholder Value in Indian Pharmaceutical Industry: An Empirical Approach Through Created Shareholder Value. Global Business Review, 2018. 19(5): p. 1290-1302.

5. McWilliams, A. and D. Siegel, Corporate social responsibility: A theory of the firm perspective. Academy of management review, 2001. 26(1): p. 117-127.

6. McWilliams, A. and D. Siegel, Profit maximizing corporate social responsibility. Academy of Management Review, 2001. 26(4): p. 504 505.

7. Dibella, M. and J. Woodilla, Corporate social responsibility and financial performance. Econ. Res, 2006. 30: p. 676-693.

8. Sanil, H. and M.I. Qureshi, Multifaceted Meaning of Corporate Social Responsibility (CSR) : A Case Study Among Insurance Company, Non-Government Organization and the Government. 2019. 7: p. 868 872 .

9. Sayed, S., et al., Does Corporate Social Responsibility Improve the Firm's Financial Performance: A Theoretical Perspective of Agency and Stakeholder Theory by Financial Sector of Pakistan. Journal of Contemporary Management Sciences, 2017. 3: p. 137-156.

10. Venugopal, M., R. Reddy, and B.P.S. G., Shareholder Value Creation: A Review of the Theoretical and Empirical Literature. Asia-Pacific Journal of Management Research and Innovation, 2018. 14(3-4): p. 74-80.

11. Windsor, D. and J. Boatright, Shareholder wealth maximization. Finance ethics: Critical issues in theory and practice, 2010: p. 437 455.

12. Carroll, A.B. and K.M. Shabana, The business case for corporate social responsibility: A review of concepts, research and practice. International journal of management reviews, 2010. 12(1): p. 85-105.

13. Borde, N., Shareholder value creation in indian companies: an empirical study. 2012, Goa University.

14. Arora, P. and R. Dharwadkar, Corporate governance and corporate social responsibility (CSR): The moderating roles of attainment discrepancy and organization slack. Corporate governance: an international review, 2011. 19(2): p. 136-152.

15. Schmidt, K. What Is Corporate Social Responsibility? 2019 [cited 21 september 2019; Available from: https://www.businessnewsdaily.com/4679-corporate-socialresponsibility.html.

16. El Akremi, A., et al., How do employees perceive corporate responsibility? Development and validation of a multidimensional corporate stakeholder responsibility scale. Journal of Management, 2018. 44(2): p. 619-657.

17. Carmeli, A., G. Gilat, and D.A. Waldman, The role of perceived organizational performance in organizational identification, adjustment and job performance. Journal of Management Studies, 2007. 44(6): p. 972-992.

18. Hopkins, M., Definition of Corporate Social Responsibility. MHC Monthly Feature, 2011

19. Wood, D.J., Measuring corporate social performance: A review. International Journal of Management Reviews, 2010. 12(1): p. 50-84.

20. Adams, C.A. and G.R. Frost, Accessibility and functionality of the corporate web site: implications for sustainability reporting. Business Strategy and the Environment, 2006. 15(4): p. 275-287.

21. Gulyás, Á., Corporate social responsibility in the British media industries - preliminary findings. Media, Culture \& Society, 2009. 31(4): p. 657-668.

22. Young, S. and V. Thyil, Corporate social responsibility and corporate governance: Role of context in international settings. Journal of Business Ethics, 2014. 122(1): p. 1-24.

23. Carroll, A.B., A three-dimensional conceptual model of corporate performance. Academy of management review, 1979. 4(4): p. $497-$ 505 .
24. Margolis, J.D. and J.P. Walsh, People and profits?: The search for a link between a company's social and financial performance. 2001: Psychology Press.

25. Fernando, M., Corporate social responsibility in the wake of the asian tsunami:: A comparative case study of two sri lankan companies European Management Journal, 2007. 25(1): p. 1-10.

26. Hishan, S.S., et al., Corporate social and enviornmental disclosure among malaysian listed companies. International Journal of Recent Technology and Engineering, 2019. 7(6): p. 1606-1608

27. Iwu-Egwuonwu, D. and R. Chibuike, Does corporate social responsibility (CSR) impact on firm performance? A literature evidence. Ronald Chibuike, Does Corporate Social Responsibility (CSR) Impact on Firm Performance, 2010.

28. Bae, K.-H., et al., Does corporate social responsibility reduce the costs of high leverage? Evidence from capital structure and product market interactions. Journal of Banking \& Finance, 2019. 100: p. 135150

29. Kitzmueller, M. and J. Shimshack, Economic perspectives on corporate social responsibility. Journal of Economic Literature, 2012. 50(1): p. 51-84.

30. Albuquerque, R., Y. Koskinen, and C. Zhang, Corporate social responsibility and firm risk: Theory and empirical evidence. Management Science, 2018.

31. Hong, H. and I. Liskovich, Crime, punishment and the halo effect of corporate social responsibility. 2015, National Bureau of Economic Research.

32. Lins, K.V., H. Servaes, and A. Tamayo, Social capital, trust, and firm performance: The value of corporate social responsibility during the financial crisis. The Journal of Finance, 2017. 72(4): p. 1785-1824.

33. Waddock, S.A. and S.B. Graves, The corporate social performancefinancial performance link. Strategic management journal, 1997. 18(4): p. 303-319.

34. Hong, H. and M. Kacperczyk, The price of sin: The effects of social norms on markets. Journal of Financial Economics, 2009. 93(1): p. 15-36.

35. El Ghoul, S., et al., Does corporate social responsibility affect the cost of capital? Journal of Banking \& Finance, 2011. 35(9): p. 2388-2406.

36. Merton, R.C., A simple model of capital market equilibrium with incomplete information. The journal of finance, 1987. 42(3): p. 483 510 .

37. Heinkel, R., A. Kraus, and J. Zechner, The effect of green investment on corporate behavior. Journal of financial and quantitative analysis, 2001. 36(4): p. 431-449.

38. Gao, H., K. Li, and Y. Ma, Stakeholder orientation and the cost of debt: Evidence from a natural experiment. 2017, SSRN Working paper.

39. Abor, J. and N. Biekpe, SMEs' access to debt finance: A comparison of male-owned and female-owned businesses in Ghana. The International Journal of Entrepreneurship and Innovation, 2006. 7(2): p. $105-112$.

40. Erol, T., Strategic debt with diverse maturity in developing countries: Industry-level evidence from Turkey. Emerging Markets Finance and Trade, 2004. 40(5): p. 5-24.

41. Kannadhasan, M., V. Goyal, and P. Charan, The Role of Financial Performance as a Moderator on the Relationship Between Financial Leverage and Shareholders Return. Journal of Modern Accounting and Auditing, 2016. 12(7): p. 81-98.

42. Kaur, M. and S. Narang, EVA® disclosures in the annual reports of Indian companies: An empirical study. Global Business Review, 2010. 11(3): p. 395-420.

43. Oino, I. and B. Ukaegbu, The impact of profitability on capital structure and speed of adjustment: An empirical examination of selected firms in Nigerian Stock Exchange. Research in International Business and Finance, 2015. 35: p. 111-121.

44. Vătavu, S., The impact of capital structure on financial performance in Romanian listed companies. Procedia Economics and Finance, 2015. 32: p. 1314-1322.

45. Hedayatzadeh, S.H.-a., The relationship between capital structure and corporate performance of pharmaceutical accepted in the Tehran stock exchange. Advances in Environmental Biology, 2013. 7(11): p 3388-3395. 
46. Atiyet, B.A., The impact of financing decision on the shareholder value creation. Journal of Business Studies Quarterly, 2012. 4(1): p. 44.

47. Mansell, S., Book review: rejoinder to Veldman's review of capitalism, corporations and the social contract: A critique of stakeholder theory. Vol. 22. 2015: Sage Publications Sage UK: London, England.

48. Parmar, B.L., et al., Stakeholder theory: The state of the art. The academy of management annals, 2010. 4(1): p. 403-445

49. Agle, B.R., et al., Dialogue: Toward superior stakeholder theory. Business Ethics Quarterly, 2008. 18(2): p. 153-190.

50. Donaldson, T. and L.E. Preston, The stakeholder theory of the corporation: Concepts, evidence, and implications. Academy of management Review, 1995. 20(1): p. 65-91.

51. Pastoors, G., The influence of CSR performance on shareholders wealth. 2018

52. Adeneye, Y.B. and M. Ahmed, Corporate social responsibility and company performance. Journal of Business Studies Quarterly, 2015. 7(1): p. 151 .

53. Cochran, P.L. and R.A. Wood, Corporate social responsibility and financial performance. Academy of management Journal, 1984 27(1): p. 42-56.

54. Deegan, C. and J. Unerman, Unregulated corporate reporting decisions: considerations of systems-oriented theories. Financial accounting theory. London: McGraw-Hill, 2011.

55. Malik, M.S. and L. Kanwal, Impact of corporate social responsibility disclosure on financial performance: case study of listed pharmaceutical firms of Pakistan. Journal of Business Ethics, 2018 150(1): p. 69-78.

56. Freeman, R.E., A.C. Wicks, and B. Parmar, Stakeholder theory and "the corporate objective revisited". Organization science, 2004. 15(3): p. 364-369.

57. Freeman, R., 1984, Strategic Management: A stakeholder approach Boston: Pitman. 1984.

58. Jensen, M.C. and W.H. Meckling, Theory of the firm: Managerial behavior, agency costs and ownership structure. Journal of financial economics, 1976. 3(4): p. 305-360.

59. Jensen, M.C., Agency costs of free cash flow, corporate finance, and takeovers. The American economic review, 1986. 76(2): p. 323-329.

60. Aryani, D.N. and B.E. Niron. Good Corporate Governance on Corporate Social Responsibility with Profitability, Size and Leverage as Moderating Variables (case study at Regional Development Banks in Indonesia). in 1st International Conference on Intellectuals' Global Responsibility (ICIGR 2017). 2018. Atlantis Press.

61. Gulzar, M., et al., The Impact of Board Gender Diversity and Foreign Institutional Investors on the Corporate Social Responsibility (CSR) Engagement of Chinese Listed Companies. Sustainability, 2019. 11(2): p. 307

62. Myers, S.C., Determinants of corporate borrowing. Journal of financial economics, 1977. 5(2): p. 147-175.

63. Williams, J., Perquisites, risk, and capital structure. The Journal of Finance, 1987. 42(1): p. 29-48.

64. Harris, M. and A. Raviv, Capital structure and the informational role of debt. The Journal of Finance, 1990. 45(2): p. 321-349.

65. Stulz, R., Managerial discretion and optimal financing policies. Journal of financial Economics, 1990. 26(1): p. 3-27.

66. Zikmund, W., et al., Business Research Methods, 9th International Edition. South-Western Cengage Learning, Canada, 2013.

67. Baker, M., Why CSR reporting is broken and how it should be fixed Sustainability reporting will undergo a revolution in the next few years. This can only be a good thing argues Mallen Baker. Retrieved

68. Zerk, J.A., Multinationals and corporate social responsibility: Limitations and opportunities in international law. Vol. 48. 2006 Cambridge University Press.

69. Ariyabandu, M.M. and P. Hulangamuwa, Corporate socia responsibility and natural disaster reduction in Sri Lanka. ITDGSouth Asia, 2002.

70. Justice, D.W., Corporate social responsibility: Challenges and opportunities for trade unionists. 2002.

71. Ghobadian, A., D. Gallear, and M. Hopkins, TQM and CSR nexus International Journal of Quality \& Reliability Management, 2007. 24(7): p. 704-721

72. Waheed, R., et al., The Role of Corporate Social Responsibility on Firms Financial Performance in Pakistan. 2016.

73. Alchian, A.A., Uncertainty, Evolution, and Economic Theory. 1958 Irwin.

74. Friedman, M., Excerpts from Milton Friedman, Capitalism and Freedom. Chapter, 1962. 1: p. 7-17. June 30, 2009. 2008

75. Baron, R.M. and D.A. Kenny, The moderator-mediator variable distinction in social psychological research: Conceptual, strategic, and statistical considerations. Journal of personality and social psychology, 1986. 51(6): p. 1173.

76. James, L.R. and J.M. Brett, Mediators, moderators, and tests for mediation. Journal of applied psychology, 1984. 69(2): p. 307.

77. Pratama, Y.A., D. Amboningtyas, and Y. Yulianeu, THE INFLUENCE OF GOOD CORPORATE GOVERNANCE AND FINANCIAL LEVERAGE TO PROFITABILITY WITH CORPORATE SOCIAL RESPONSIBILITY AS INTERVENING VARIABLE (CASE STRUDY ON MANUFACTURING COMPANIES LISTED ON BEI PERIOD 2012-2016). Journal of Management, 2017. 3(3)

78. Bhardwaj, A., Financial Leverage and Firm's Value: A study of capital Structure of Selected Manufacturing Sector Firms in India. 2018.

79. Al-Rdaydeh, M., Moderating effect of competitive strategies on the relation between financial leverage and firm performance: Evidence from Jordan. Business and Economic Horizons, 2018. 14(3): p. 626641

80. Zhu, C., et al., The leverage effect on wealth distribution in a controllable laboratory stock market. PloS one, 2014. 9(6): p e100681.

81. Di Giuli, A. and L. Kostovetsky, Are red or blue companies more likely to go green? Politics and corporate social responsibility. Journal of Financial Economics, 2014. 111(1): p. 158-180.

82. Subramanyam, K. and J.J. Wild, Analisis Laporan Keuangan (financial statement analysis). Edisi Sepuluh. Salemba Empat: Jakarta, 2010.

83. Gupta, S., Analysis of leverage ratio in selected Indian public sector and private sector banks. Asian Journal of Management Research, 2012. 3(1): p. 12-19

84. Ross, S.A., et al., Corporate finance. 2013: McGraw-Hill/Irwin.

85. Sutojo, S. and K. Fritz, Manajemen Keuangan Bagi Eksekutif NonKeuangan. PT. Damar Mulai Perkasa. Jakarta, 2004.

86. Purnasiwi, J. and S. SUDARNO, Analisis Pengaruh Size, Profitabilitas dan Leverage Terhadap Pengungkapan CSR pada Perusahaan yang Terdaftar di Bursa Efek Indonesia. 2011, Universitas Diponegoro.

87. Brigham, E.F. and J.F. Houston, Fundamentals of financia management. 2012: Cengage Learning.

88. Trisnawati, R., Pengaruh Ukuran Perusahaan, Profitabilitas, Leverage, Ukuran Dewan Komisaris Dan Kepemilikan Manajerial Terhadap Pengungkap-An Corporate Social Responsibility (CSR) Industri Perbankan di Indonesia. 2014.

89. Fahmi, I., Analisis kinerja keuangan. Bandung: Alfabeta, 2012.

90. Husnan, S., Dasar-Dasar Portofolio dan Analisis sekuritas, Edisi Ketiga. UPP AMP YKPN, Yogyakarta, 2001

91. Freeman, R.E., The politics of stakeholder theory: Some future directions. Business ethics quarterly, 1994: p. 409-421.

92. Statman, M. and D. Glushkov, The wages of social responsibility. Financial Analysts Journal, 2009. 65(4): p. 33-46.

93. Filbeck, G., R. Gorman, and X. Zhao, The "best corporate citizens": are they good for their shareholders? Financial Review, 2009. 44(2): p. 239-262.

94. Jo, H. and M.A. Harjoto, Corporate governance and firm value: The impact of corporate social responsibility. Journal of business ethics, 2011. 103(3): p. 351-383.

95. Jo, H. and M.A. Harjoto, The causal effect of corporate governance on corporate social responsibility. Journal of business ethics, 2012 106(1): p. 53-72.

96. Cormier, D. and M. Magnan, The revisited contribution of environmental reporting to investors' valuation of a firm's earnings An international perspective. Ecological economics, 2007. 62(3-4): p. 613-626.

97. Aerts, W., D. Cormier, and M. Magnan, Corporate environmenta disclosure, financial markets and the media: An international perspective. Ecological Economics, 2008. 64(3): p. 643-659.

98. Davis, K. The case for and against business assumption of social responsibilities. Academy of Management journal, 1973. 16(2): p 312-322.

99. Javeed, S. and L. Lefen, An Analysis of Corporate Social Responsibility and Firm Performance with Moderating Effects of CEO Power and Ownership Structure: A Case Study of the Manufacturing Sector of Pakistan. Sustainability, 2019. 11(1): p. 248.

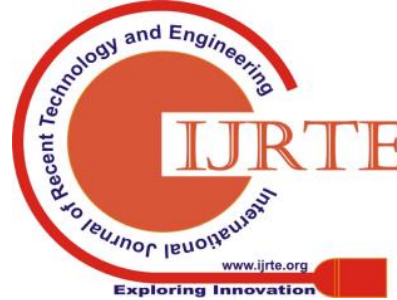




\section{Corporate Social Responsibility on Shareholder Value with Leverage as Moderating Variable}

100. Wahba, H. and K. Elsayed, The effect of institutional investor type on the relationship between CEO duality and financial performance. International Journal of Business Governance and Ethics, 2014. 9(3): p. 221-242.

101. Mujahid, M. and A. Abdullah, Impact of corporate social responsibility on firms financial performance and shareholders wealth. European Journal of Business and Management, 2014. 6(31): p. 181-187.

102. Ryu, D., D. Ryu, and J.H. Hwang, Corporate social responsibility, market competition, and shareholder wealth. Investment Analysts Journal, 2016. 45(1): p. 16-30.

103. Ali, S., et al., Moderating Role Of Ownership In Relationship Between CSRD And Firm Performance. The Journal of Developing Areas, 2019. 53(3).

104. Wen, W. and J. Song, Can returnee managers promote CSR performance? Evidence from China. Frontiers of Business Research in China, 2017. 11(1): p. 12.

105. Ramly, Z., Impact of corporate governance quality on the cost of equity capital in an emerging market: Evidence from Malaysian listed firms. African Journal of Business Management, 2012. 6(4): p. 1733 1748.

106. Brigham, E.F. and M.C. Ehrhardt, Financial management: theory and practice. 10 th. Melbourne: Thomson Learning, 2002.

107. Firer, C.R., S.A. ; Westerfield, R.W. ; Jordan, B.D., Fundamentals of Corporate Finance. McGraw-Hil, 2008.

108. Gitman, L.J., R. Juchau, and J. Flanagan, Principles of managerial finance. 2015: Pearson Higher Education AU.

109. Agus, S., Manajemen Keuangan Teori dan Aplikasi (Edisi 4). Yogyakarta: BPFE, 2010.

110. Belkaoui, A. and P.G. Karpik, Determinants of the corporate decision to disclose social information. Accounting, Auditing \& Accountability Journal, 1989. 2(1)

111. Sembiring, E.R., Karakteristik perusahaan dan pengungkapan tanggung jawab sosial: study empiris pada perusahaan yang tercatat di Bursa Efek Jakarta. MAKSI, 2006. 6.

112. Sriayu, G.A.P.W. and N.P.S.H. Mimba, Pengaruh karakteristik perusahaan terhadap corporate social responsibility disclosure. EJurnal Akuntansi, 2013: p. 326-344.

113. Wijaya, M., Faktor-faktor yang mempengaruhi pengungkapan tanggung jawab sosial pada perusahaan manufaktur yang terdaftar di Bursa Efek Indonesia. Jurnal Ilmiah Mahasiswa Akuntansi, 2012. 1(1): p. 26-30.

114. Satyo, N.K., Sustainability Reporting: Paradigma Baru Pelaporan Perusahaan. Media Akuntansi. Edisi, 2005. 47: p. 7-9.

115. Fernández-Gago, R., L. Cabeza-García, and M. Nieto, Independent directors' background and CSR disclosure. Corporate Social Responsibility and Environmental Management, 2018. 25(5): p. 9911001.

116. Kim, Y.-B., H.T. An, and J.D. Kim, The effect of carbon risk on the cost of equity capital. Journal of Cleaner Production, 2015. 93: p 279-287.

117. Modugu, K.P. and S.U. Eboigbe, Corporate attributes and corporate disclosure level of listed companies in Nigeria: a post-IFRS adoption study. Journal of Finance and Accounting, 2017. 5(2): p. 44-52.

118. Ashmarina, S., A. Zotova, and E. Smolina, Implementation of financial sustainability in organizations through valuation of financial leverage effect in Russian practice of financial management. International journal of environmental \& science education, 2016. 11(10): p. 3775-3782.

119. Bhatnagar, V.K., M. Kumari, and N. Sharma, Impact of Capital Structure \& Cost of Capital on Shareholders' Wealth Maximization-A Study of BSE Listed Companies in India. Chanakya International Journal of Business Research, 2015. 1(1): p. 28-36.

120. Fauzi, H., Corporate social and financial performance: Empirical evidence from American companies. Globsyn Management Journal, Forthcoming, 2009.

121. Susanti, F., M. Fenny, and I. Rini, The influence of corporate social responsibility to firm value with profitability and leverage as a moderating variable. 2012.

\section{AUTHORS PROFILE}

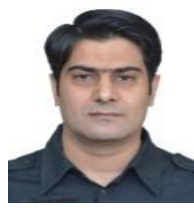

Asim Ali Chaudhry, Ph.D. Scholar in Azman Hashim International Business School at Universiti Teknologi Malaysia, Johor Bahru, Skudai Malaysia $2^{\text {nd }}$ publication in the Scopus journal.

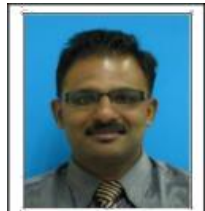

Dr. Suresh Ramakrishnan, Associate Professor, Deputy Dean (Research, Innovation, Development \& Alumni), Azman Hashim International Business School, Universiti Teknologi Malaysia.

$\mathrm{Ph}$. D (Finance), Deakin University Australia, Melbourne. Scopus Journal 44 publications Ayesha Sharif, Ph.D. Scholar in Azman Hashim International Business School at Universiti Teknologi Malaysia, Johor Bahru, Skudai, Malaysia 